\title{
Peran guru PPKn sebagai evaluator dalam meningkatkan disiplin belajar siswa
}

\author{
Erni Novianti ${ }^{a, 1^{*}}$, Yudi Firmansyah ${ }^{\mathrm{b}, 2}$, Erwin Susanto ${ }^{c, 3}$ \\ abc Pendidikan Pancasila dan Kewarganegaraan, Universitas Buana Perjuangan Karawang, Indonesia \\ a, 1 pk16.erninovianti@mhs.ubpkarawang.ac.id* \\ *korespondensi penulis
}

\section{ABSTRAK}

Penelitian ini bertujuan menjelaskan bagaimana peran guru Pendidikan Pancasila dan Kewarganegaraan (PPKn) sebagai evaluator dalam meningkatkan disiplin belajar siswa kelas VIII SMPN 1 Telagasari. Penelitian ini menggunakan pendekatan kualitatif dengan metode deskriptif. Subjek dalam penelitian ini adalah guru Pendidikan Pancasila dan Kewarganegaraan (PPKn) serta siswa dari kelas VIII. Teknik pengumpulan data menggunakan observasi, wawancara dan dokumentasi. Teknik analisis dilakukan dengan tiga alur tahap kegiatan yaitu reduksi data, penyajian data dan kesimpulan. Hasil dari penelitian ini dalam meningkatkan disiplin belajar siswa, guru Pendidikan Pancasila dan Kewarganegaraan (PPKn) sebagai evaluator melakukan evaluasi pembelajaran secara terus-menerus untuk melihat keberhasilan siswa dalam belajar dan dapat meningkatkan disiplin belajar siswa apabila dari hasil evaluasi belajar siswa belum menunjukan keberhasilan. Rekomendasi penelitian ini, bagi kepala sekolah sebagai pemimpin dan pembuat kebijakan diharapkan dapat meningkatkan profesionalitas kerja guru sehingga guru dapat melakukan perannya dengan baik ketika mengajar serta memperketat dan meningkatkan siswa dalam mematuhi peraturan mengenai kedisiplinan di sekolah. Bagi guru, diharapkan untuk selalu memperhatikan perilaku disiplin siswa terutama saat kegiatan belajar di dalam kelas. Bagi siswa, diharapkan untuk lebih meningkatkan perilaku disiplin dalam mematuhi peraturan yang ada di sekolah atau di dalam kelas saat belajar. Bagi peneliti selanjutnya, semoga penelitian ini dapat menjadi bahan perbandingan dan referensi serta dapat dikembangkan sebagai bahan penelitian selanjutnya.

\section{ABSTRACT}

The purpose of this research is to explain the role of the teacher of Pancasila and Civic Education (PPKn) as the evaluator in improving the learning discipline of the 8th-grade students in SMPN 1 Tegalsari. This research used a qualitative approach with a descriptive method. The subjects of this research are the teacher of Pancasila and Civic Education (PPKn) and the 8th-grade students. The data in this research were collected through observations, interviews, and context documentation. The analysis of data was conducted in three stages; data reduction, data display, and conclusion drawing. The result of research shows that in improving students' learning discipline, the teacher of Pancasila and Civic Education (PPKn), as the evaluator, had fulfilled the role by evaluating the learning process regularly to observe students' learning achievement and taking an action when the result of learning evaluation is lacking. There are several recommendations from this research. The headmaster as the chief and the policymaker is expected to be able to improve teachers' work professionalism so they can teach better. The school also expected to be always strict and make sure the students follow the rules of discipline. For teachers, they are expected to always monitor students' behavior during learning activity in class. For students, they are expected to improve their behavior discipline in following both the rules of school and classroom. Additionally, for the next researcher, hopefully, this research can be used as the comparative study, the reference, and can be developed as the material for the next research.

Informasi Artikel

Diterima: 10 Mei 2020

Disetujui: 25 juli 2020

Kata kunci:

Guru PPKn

Evaluator

Disiplin belajar

Articles's Information:

Received: 10 May 2020

Accepted: 25 July 2020

Keywords:

Civic teacher

Evaluator

Llearning discipline 


\section{Pendahuluan}

Pendidikan merupakan kegiatan yang hanya dapat dilakukan oleh manusia. Ruang lingkup lapangan pendidikan mencakup semua pengalaman dan pemikiran manusia tentang pedidikan. Undang-undang Sistem Pendidikan Nasional No. 20 Tahun 2003 menyatakan bahwa: "Pendidikan adalah usaha sadar dan terencana dalam mewujudkan suasana belajar dan proses pembelajaran agar peserta didik secara aktif mengembangkan potensi dirinya untuk memiliki kekuatan spiritual keagamaan, pengendalian diri, kepribadian, kecerdasan, akhlak mulia serta keterampilan yang diperlukan dirinya, masyarakat, bangsa dan Negara"

Mata pelajaran Pendidikan Pancasila dan Kewarganegaraan menekankan pada pembinaan terhadap perilaku warga Negara yang memiliki keberagaman untuk dapat menjalankan hak dan kewajibannya sebagai warga Negara Indonesia yang cerdas, terampil dan berkarakter. Susanto dan Komalasari (2015) bahwa: "Pembelajaran Pendidikan Pancasila dan Kewarganegaraan dengan memperhatikan sejumlah komponen belajar mengajar secara tepat, meliputi tujuan, bahan pelajaran, kegiatan belajar mengajar, metode, alat dan sumber serta evaluasi akan menunjang suasana pembelajaran yang senantiasa membelajarkan tiga kompetensi dasar yang harus dimiliki oleh siswa, yaitu: pertama, pengetahuan kewarganegaraan. Kedua, kecakapan kewarganegaraan. Ketiga, watak kewarganegaraan".

Keberhasilan siswa dalam belajar dapat dilihat dari hasil evaluasi belajar siswa. Peran guru sebagai evaluator di dalam kelas sangat diperlukan, karena guru dapat melihat ketercapaian siswa dalam belajar melalui perannya sebagai evaluator. Peran guru di dalam kelas sebagai evaluator tidak hanya memberikan penilaian kepada siswa tetapi guru dapat mengembangkan dan meningkatkan belajar siswa apabila dari hasil evaluasi siswa belum menunjukan keberhasilan dalam belajar dengan membina perilaku disiplin siswa dalam belajar serta meningkatkan keterampilan siswa dalam belajar. Melalui peran guru sebagai evaluator di dalam kelas dapat meningkatkan disiplin belajar pada siswa dengan melakukan perubahan dalam belajar agar siswa lebih tertib ketika belajar.

Mencapai keberhasilan siswa dalam belajar dapat dilakukan dengan membentuk perilaku siswa untuk disiplin dalam belajar. Ardi (2015) "Disiplin belajar siswa adalah usaha untuk membina kesadaran siswa secara terus-menerus dalam belajar agar belajar dengan baik sesuai dengan fungsinya yang tergabung dalam suatu organisasi dan tunduk pada aturan-aturan yang telah ada". Disiplin belajar di dalam kelas merupakan keadaan kelas yang tertib di mana kegiatan belajar mengajar dapat tercapai dengan efektif. Masalah disiplin belajar siswa seperti mengobrol saat kegiatan belajar mengajar, tidur di dalam kelas saat guru mengajar, keadaan kelas yang tidak beraturan dan lain sebagainya dapat menghambat dan mengganggu proses pembelajaran. Maka dari itu, untuk melihat dan mencapai keberhasilan siswa dalam belajar diperlukan peran guru sebagai evaluator dalam mengembangkan dan membina perilaku siswa dalam kegiatan belajar. Dalam konteks pembelajaran PKn, dikatakan bahwa: more important are the activities that people not only understand in theory but was able to participate on the grounds that they understand the concept and what it does impact on them (Susanto \& Saylendra, 2018). Yaitu untuk membentuk warga negara yang baik diperlukan warganegara yang tidak hanya paham teori tetapi juga mampu melaksanakan teori tersebut. Artinya, siswa juga harus dibentuk untuk menjdi warga negara yang tidak hanya disiplin, namun ia mampu untuk menjalankan setiap hak dan kewajibannya.

Menyikapi penjelasan di atas, mengenai disiplin belajar yang dapat mempengaruhi proses pembelajaran serta pentingnya peran guru dalam meningkatkan disiplin belajar siswa terutama guru Pendidikan Pancasila dan Kewarganegaraan yang dalam pembelajarannya lebih banyak mengajarkan tentang nilai-nilai, etika, sopan santun dan kedisiplinan. Maka peneliti melakukan observasi sementara mengenai kedisiplinan siswa di SMP Negeri 1 Telagasari. Hasil observasi sementara 
menunjukan bahwa masih ada siswa yang berada di luar kelas pada saat jam pelajaran, siswa yang berpakaian tidak rapih dan siswa yang terlambat masuk kelas. Untuk itu, peneliti dapat menyimpulkan bahwa masih kurangnya perilaku disiplin siswa di sekolah terutama disiplin dalam belajar dan kurangnya peran guru dalam meningkatkan disiplin belajar siswa. Maka dari itu, diperlukan peran guru dalam meningkatkan disiplin belajar siswa untuk mencapai keberhasilan belajar. Berdasarkan permasalahan tersebut, peneliti melakukan penelitian terhadap Peran Guru Pendidikan Pancasila dan Kewarganegaraan sebagai Pengelola Kelas dalam Meningkatkan Disiplin Belajar Siswa.

\section{Metode}

Penelitian ini menggunakan pendekatan kualitatif dengan metode deskriptif. Subjek dalam penelitian ini adalah guru Pendidikan Pancasila dan Kewarganegaraan serta 3 orang siswa dari kelas VIII SMPN 1 Telagasari. Teknik pengumpulan data menggunakan observasi, wawancara dan dokumentasi. Keabsahan data menggunakan triangulasi sumebr. Teknik analisis data dilakukan dengan tiga alur tahap kegiatan yaitu, reduksi data, penyajian data kemudian penarikan kesimpulan.

\section{Hasil dan Pembahasan}

Keberhasilan siswa dalam belajar dapat dipengaruhi oleh perilaku siswa yang disiplin dalam belajar. Untuk itu, diperlukan peran guru sebagai evaluator dalam meningkatkan disiplin belajar siswa untuk mengetahui dan mencapai keberhasilan siswa dalam belajar. Hasil penelitian menunjukan bahwa guru Pendidikan Pancasila dan Kewarganegaraan SMPN 1 Telagasari dalam meningkatkan disiplin belajar siswa melalui perannya sebagai evaluator melakukan evaluasi pembelajaran seperti membuat rangkuman hasil belajar, setelah itu mengajukan pertanyaan diakhir pembelajaran yang mendorong keaktifan siswa dalam kegiatan belajar sebagai bentuk penilaian yang dilakukan. Dalam meningkatkan disiplin belajar peran guru Pendidikan Pancasila dan Kewarganegaraan sebagai evaluator melakukan penilaian secara terus-menerus dan berulang-ulang untuk melihat keberhasilan siswa dalam belajar. Apabila dari hasil evaluasi belajar menunjukan siswa belum mencapai hasil belajar yang maksimal maka guru Pendidikan Pancasila dan Kewarganegaraan melakukan upaya untuk terus mengikuti perkembangan siswa dalam kegiatan belajar dengan meningkatkan perilaku disiplin siswa melalui bimbingan dan arahan agar siswa dapat mencapai hasil belajar yang diharapkan.

Sesuai dengan teori yang menjelaskan peran guru sebagai evaluator terdapat dalam penelitian Arifudin (2015) yaitu sebagai berikut: "Peranan guru sebagai evaluator harus dilakukan secara terus menerus melihat tingkat keberhasilan, efektivitas dan efisiensi dalam proses pembelajaran. Dari hasil evaluasi yang dilakukan akan menjadi tolak ukur dalam meningkatkan hasil belajar siswa dalam setiap proses pembelajaran yang dilakukan guru di kelas". Selain itu teori yang mengemukakan peran guru sebagai evaluator terdapat dalam penelitian Hamidah (2018) yaitu sebagai berikut: "Guru sebagai evaluator ialah memberikan penilaian. Fungsi ini dimaksudkan agar guru mengetahui apakah tujuan yang telah dirumuskan telah tercapai atau belum, dan apakah materi yang sudah diajarkan sudah cukup tepat. Dengan melakukan penilaian guru akan dapat mengetahui keberhasilan pencapaian tujuan, penguasaan siswa terhadap pelajaran serta keefektifan metode mengajar. Dalam peran ini, guru menyimpulkan data atau informasi tentang keberhasilan pembelajaran yang telah dilakukan".

Selain pembelajarannya yang berkaitan dengan kedisiplinan, peran guru Pendidikan Pancasila dan Kewarganegaraan sebagai evaluator dalam meningkatkan disiplin belajar dapat mengembangkan dan membentuk karakter disiplin pada siswa untuk menjadi warga negara yang baik sebagai calon generasi penerus bangsa. Mutmainah dan Kamaludin (2018), menjelaskan peran guru Pendidikan Pancasila dan Kewarganegaraan dalam membentuk sikap dan kepribadian siswa, dapat dilakukan 
beberapa cara adalah membentuk sikap siswa yang mempertahankan hak dan kewajibannya serta mampu melaksanakan hak dan kewajibannya dengan baik, membentuk siswa yang memiliki rasa cinta terhadap tanah air serta memiliki rasa kebangsaan yang kuat, membentuk siswa yang dapat menghormati orang dalam kehidupan di sekolah maupun di masyarakat serta mentaati aturan-aturan yang ada di sekolah termasuk pada proses belajar mengajar, membentuk siswa yang dapat melaksanakan musyawarah dalam mengambil keputusan baik di sekolah maupun di masyarakat, dan dapat membentuk siswa yang mengakui bahwa Indonesia ini adalah Negara yang plural yaitu terdiri dari berbagai macam agama, suku, bangsa dan budaya.

Selain itu, peran guru Pendidikan Pancasila dan Kewarganegaraan SMPN 1 Telagasari sebagai evaluator melakukan penilaian dengan melihat siswa mampu memiliki kompetensi pengetahuan kewarganegaraan, keterampilan kewarganegaraan dan watak kewarganegaraan sebagai indikator penilaian yang dilakukan. Sesuai dengan pendapat Susanto dan Komalasari (2015) bahwa: "Pembelajaran Pendidikan Pancasila dan Kewarganegaraan dengan memperhatikan sejumlah komponen belajar mengajar secara tepat, meliputi tujuan, bahan pelajaran, kegiatan belajar mengajar, metode, alat dan sumber serta evaluasi akan menunjang suasana pembelajaran yang senantiasa membelajarkan tiga kompetensi dasar yang harus dimiliki oleh siswa, yaitu: pertama, pengetahuan kewarganegaraan. Kedua, kecakapan kewarganegaraan. Ketiga, watak kewarganegaraan".

Berdasarkan penjelasan di atas, peran guru Pendidikan Pancasila dan Kewarganegaraan sebagai evaluator dalam meningkatkan disiplin belajar siswa dengan melakukan evaluasi pembelajaran secara teru-menerus untuk mencapai keberhasilan siswa dalam kegiatan belajar dengan membina perilaku disiplin siswa dalam belajar, membuat bentuk penilaian yang mendorong keaktifan siswa dalam kegiatan belajar dan melakukan penilaian dengan melihat siswa mampu memiliki kompetensi pengetahuan kewarganegaraan, keterampilan kewarganegaraan dan watak kewarganegaraan sebagai indikator penilaian disiplin.

\section{Simpulan}

Berdasarkan hasil penelitian dan pembahasan, maka peneliti dapat menyimpulkan bahwa peran guru Pendidikan Pancasila dan Kewarganegaraan sebagai evaluator melakukan evaluasi pembelajaran secara terus-menerus untuk melihat keberhasilan siswa dalam belajar dan dapat meningkatkan disiplin belajar pada siswa apabila dari hasil evaluasi belajar siswa menunjukan belum mencapai hasil belajar yang maksimal. Selain itu membuat bentuk penilaian yang mendorong keaktifan siswa dalam kegiatan belajar dan melakukan penilaian dengan melihat siswa mampu memiliki kompetensi pengetahuan kewarganegaraan, keterampilan kewarganegaraan dan watak kewarganegaraan sebagai indikator penilaian disiplin. Saran dalam penelitian ini, bagi kepala sekolah sebagai pemimpin dan pembuat kebijakan diharapkan dapat menigkatkan profesionalitas guru sehingga guru dapat melakukan perannya sebagai evaluator dengan baik serta memperketat dan meningkatkan perilaku siswa untuk disiplin dalam mematuhi peraturan yang ada di sekolah. Bagi guru, diharapkan untuk selalu memperhatikan perilaku disiplin siswa terutama saat kegiatan belajar di dalam kelas agar kegiatan belajar mengajar dapat berjalan dengan tertib dan tujuan pembelajaran dapat tercapai dengan baik. Bagi siswa, diharapkan untuk lebih meningkatkan perilaku disiplin dalam mematuhi peraturan yang ada di sekolah atau di dalam kelas saat belajar seperti membiasakan diri untuk berperilaku disiplin dalam belajar dengan memperhatikan guru saat mengajar, tidak mengobrol serta berpakaian rapih dan sebagainya. Bagi peneliti selanjutnya yang akan meneliti dengan tema yang sama semoga penelitian ini dapat menjadi bahan perbandingan dan referensi serta dapat dikembangkan sebagai bahan penelitian selanjutnya. 


\section{Ucapan Terima Kasih}

Peneliti mengucapkan terimakasih kepada kepada bapak Yudi Firmansyah, S.Pd., M.Pd selaku dosen pembimbing pertama dan Bapak Erwin Susanto, S.Pd., M.Pd selaku dosen pembimbing kedua yang telah banyak membantu mengarahkan dan membimbing dalam menyelesaikan penelitian maupun dalam pembuatan artikel ini sehingga dapat selesai tepat waktu.

\section{Referensi}

Ardi, M. (2015). Pengaruh Pemberian Hukuman Terhadap Disiplin Siswa Dalam Belajar (Penelitian Eksperimen di Kelas VIII Sekolah Menengah Pertama Negeri 1 Nanga Tebidah Kecamatan Kayan Hulu Kabupaten Sintang). Jurnal Eksos, 8(1), 61-72.

Arifudin, I. S. (2015). Peranan Guru Terhadap Pendidikan Karakter Siswa Di Kelas V SDN 1 Siluman. PEDADIDAKTIKA: Jurnal IImiah Pendidikan Guru sekolah Dasar, 2(2), 175-186.

Hamidah, Millatun. 2018. Upaya Guru Dalam Meningkatkan Kedisiplinan Siswa SMK Muhammadiyah Parakan Tangerang Selatan. Skripsi. Jakarta: Program Studi Agama Islam Universitas Muhammadiyah Jakarta.

Mutmainah, D., \& Kamaludin. (2018). Peran Guru Pendidikan Pancasila dan Kewarganegaraan dalam Membentuk Sikap dan Kepribadian Siswa. CIVICUS: Pendidikan-Penelitian-Pengabdian Pendidikan Pancasila dan Kewarganegaraan, 6(2), 45-54.

Susanto, E., \& Komalasari, K. (2015). PENGARUH PEMBELAJARAN, HABITUASI DAN EKSTRAKURIKULER TERHADAP PEMBENTUKAN CIVIC DISPOSITION SISWA SMA NEGERI SE-KOTA BANDAR LAMPUNG. Jurnal Ilimiah Mimbar Demokrasi, 15(1), 60-68.

Susanto, E., \& Saylendra, N. P. (2018). Civic Education as Empowerment of Civic Activism. Annual Civic Education Conference.

Undang-Undang Nomor 20 Tahun 2003 Tentang Sistem Pendidikan Nasional. 2003. Jakarta: Sekretariat Negara. 